\title{
Walking Tourist: Review of Research to Date
}

\author{
Swarnali Dihingia ${ }^{1}$; Morten Gjerde ${ }^{2}$; and Brenda Vale ${ }^{3}$
}

\begin{abstract}
One of the most common activities among tourists is walking, providing visitors with a range of different experiences of the places they visit. These experiences can vary, depending on the time of the year, weather, and, most importantly, the motivations of the individual. Much attention has gone into understanding the ways in which built and natural environments create opportunities for people to walk. However, the motivations and walking behaviors of tourists can differ from those of local residents. This paper explores walkability by adopting a systematic review of literature on different databases. The descriptive theme is focused on the general importance of walkability and four major themes on tourist walking studies are identified. The findings from the studies and their limitations point toward a need for further study, with a focus on local residents and tourists in order to understand whether there are differences and to understand the attributes that may affect their walking behaviors and experiences. DOI: 10.1061/(ASCE)UP.1943-5444.0000829. (C) 2022 American Society of Civil Engineers.
\end{abstract}

\section{Introduction}

Most journeys start and end with a walk, and this ubiquitous practice has made it a fundamental activity that is both physical and social. For people walking in their local neighborhood for their daily activities or visitors strolling in the streets of an unknown city or a town, just looking can give a special pleasure, no matter how commonplace the sight might be. Every street has its own unique characteristics to attract people, and it is difficult to forget the temporal art of cities. Whether it is by walking through vibrant marketplaces and neon-lit shopping arcades filled with people or along a street winding through areas of natural beauty, stimulating experiences can be had by the simple act of walking.

Walkers interact with and experience a multitude of urban spaces (Pinder 2005). Experiences are seldom felt in isolation, but are instead sensed through time and in relation to the setting. It is the sequence of events that leads to an experience, informed also by the memories that are attached to spaces (Aho 2001; Gehl 2017). As Jan Gehl noted, "There is much more to walking than just walking."

Most people walk, even for short distances, and it can be noted that while many people have the choice to travel by other modes of transportation, some do not. By and large, able-bodied people have more transport options than those who are disabled, children, older people, and those who are financially less well off. Moreover, walking is part of almost all trips, whether by public transit, car, or bicycle; this is also known as multimodal walking. Thus, for an all-inclusive walking experience, the norms for the walking population cannot be defined by those of the most able-bodied people.

${ }^{1} \mathrm{Ph} . \mathrm{D}$. Candidate, Architecture and Design, Victoria Univ. of Wellington, Wellington 6011, New Zealand (corresponding author). ORCID: https://orcid.org/0000-0003-3712-1220. Email: swarnali .dihingia@vuw.ac.nz

${ }^{2}$ Associate Professor, Architecture and Design, Victoria Univ. of Wellington, Wellington 6011, New Zealand. ORCID: https://orcid.org/0000 -0001-7317-6320. Email: morten.gjerde@vuw.ac.nz

${ }^{3}$ Professor, Architecture and Design, Victoria Univ. of Wellington, Wellington 6011, New Zealand. Email: brenda.vale@vuw.ac.nz

Note. This manuscript was submitted on July 14, 2021; approved on December 7, 2021; published online on February 22, 2022. Discussion period open until July 22, 2022; separate discussions must be submitted for individual papers. This paper is part of the Journal of Urban Planning and Development, (C) ASCE, ISSN 0733-9488.
Walking is usually recognized as an active transport mode that encourages good public and private health and well-being, contributes to a feeling of community and positive sense of place, and, importantly in the current concerns of climate and environmental change, can help reduce traffic congestion, and hence, air pollution and emissions, as well as resource depletion (Leyden 2003; Forsyth and Southworth 2008; Ewing and Handy 2009; Gilderbloom et al. 2015; Hall et al. 2017).

Tourists are another category of walker and may have different views on what makes a good walking environment. A tourist, according to the World Tourism Organization (2008), is a visitor who has traveled to a destination outside his or her usual environment for business, leisure, or any other personal purpose other than to be employed in the place being visited. Tourism involves travel from a domestic or international location, lasting for a day or longer before leaving. Given that a tourist is generally unfamiliar with the environment visited, this raises the issue as to whether the built environment affects residents and tourists differently when it comes to walking. Tourists may also walk more than residents, with some studies suggesting that many tourists believe the best way to experience a city is to walk through it (Thompson 2003; Mansouri and Ujang 2016; Hall et al. 2017). However, only a limited number of studies have specifically examined walkability from a tourist perspective, even though walking is a fundamental, universal, and significant activity associated with tourists (Ashworth and Dietvorst 1995; Thornton et al. 1997; Shaw et al. 2000; Davies 2018; Hall and Ram 2019). As Hall et al. (2017) have noted, for tourists "walking around a destination to experience the place is an attraction in its own right."

To elucidate this issue, in this paper, the literature around walking and walkability is reviewed with a particular emphasis on studies involving tourists. This research is motivated by a working hypothesis that the walking behavior of tourists is different from that of local residents and the factors that enable or constrain tourists' desires to walk are different from those affecting local residents. The paper begins with a discussion of the concept of walkability, including walking as a physical activity, and the role of urban planning and design studies in measuring the effects of the physical environment and people's psychological attributes on walking behavior. Finally, we review the literature on walkability and tourists. This review reveals that there are insufficient studies on tourist walkability to enable full understanding of the tourist 
Table 1. Number of search results from databases

\begin{tabular}{lrrrrr}
\hline Database & \multicolumn{1}{c}{2} & \multicolumn{2}{c}{3} & \multicolumn{1}{c}{4} & \multicolumn{1}{c}{5} \\
\hline Emerald & 195 & 118 & 61 & 47 & 44 \\
ProQuest & 38,297 & 11,537 & 1,696 & 1,404 & 1,373 \\
Scopus & 2,307 & 1,795 & 4 & 4 & 2 \\
PubMed & 1,250 & 614 & 1 & 1 & 0 \\
IEEE & 16 & 3 & 0 & 0 & 0 \\
Sage & 262,356 & 79,964 & 13,064 & 13,064 & 12,080 \\
Springer & 2,733 & 2,216 & 245 & 204 & 187 \\
Taylor \& Francis & 484,743 & 172,669 & 38,052 & 38,052 & 23,197 \\
Google Scholar & 47,200 & 30,800 & 16,900 & 18,100 & 17,800 \\
Web of Science & 2,527 & 1,507 & 7 & 5 & 2 \\
ScienceDirect & 375,498 & 43,552 & 3,363 & 1,520 & 1,622 \\
\hline
\end{tabular}

walking experience. In this paper, we thus aim to shed light on the gap in knowledge concerning tourist walkability, as the indicators that restrict or encourage movement could be the foundation for design for enhancing the quality of the tourist experience within the built environment.

\section{Method}

To provide an overview of the studies on tourist walkability, a systematic literature review was conducted. A systematic literature review follows a clear and iterative methodology that reduces the risk of bias (Cherrill and Donn 2020). The process for the systematic literature review was taken from Boland et al. (2017).

\section{Literature Search Results}

A number of databases were chosen (Table 1), representing a broad range of research sources. The five combinations of keywords chosen and searched for were as follows:

1. Walkability,

2. Walkability + built environment,

3. Walkability + built environment + tourist,

4. Walkability + built environment + tourist + tourist walking,

5. Walkability + built environment + tourist walking experience + public space.

Table 1 shows the number of results for each set of the keywords in each database. The search results obtained for items 4. and 5. in this list formed the focus of this research.

\section{Screening Results}

Although the search identified many studies on walking and walkability, only a few of these had a main focus on tourist walkability. The large number of results found in the databases using the keywords "Walkability" and "Built environment" were then further searched for "Tourist" and "Tourist walking experience." The search results were screened using the following steps:

1. The search in each database was concluded when only one piece of article was found to be relevant over two pages of search result.

2. The integrated results were then screened by reading the titles and abstracts for relevance.

3. Only the articles that reported studies of tourist experience and walking behavior and not any other fields were included.

4. The references of the suitable articles were then checked to find any other relevant articles, a step that proved to be quite useful. A total of 16 articles were identified for studies on walkability and tourism by using these screening steps.
Several themes and subthemes on walkability were also identified, the most cited results of which are shown in Table 2. The search result identified theoretical and empirical studies over 60 years as these were found to be the most used and referred to by those studying walking behavior.

The findings from this systematic literature review are explained next, starting with the most cited studies on walkability and then the lesser number of articles on tourist walkability.

\section{Walkability}

A key concept related to how people draw motivation to walk is referred to as walkability. Walkability, as mentioned by Abley (2005), is the measure by which to comprehend the overall walking conditions in an area and to understand which built environment feels friendly for the people living, working, shopping, enjoying their leisure, or just spending time in it. According to Southworth (2005) a place is walkable when "the built environment supports and encourages walking by providing for pedestrian comfort and safety, connecting people with varied destinations within a reasonable amount of time and effort, and offering visual interest in the journey throughout the network." It is a combination of quantitative and qualitative measurements of how enticing or deterring a place is to its pedestrians (Jane's Walk 2013). It thus seems that the built environment is important when it comes to making walking an enjoyable experience.

In the history of urban planning theories, environments for improving livability and the importance of walkability have been well acknowledged. Published scholarly work on objective and perceived built environment determinants of walking were reviewed for this paper. Objective measures such as walk score and walkability audits or indices were mainly used in earlier walkability research until the current shift toward subjective measures such as observation, interviews, and mixed approaches (Curry et al. 2009; Millington et al. 2009; Phillips et al. 2013). This shift was predominantly in order to account for the varying individual perceptions of built form and community environments that determine walking behavior (Phillips et al. 2004; Ewing and Handy 2009). It had been noted that "perceived" environmental factors are significantly associated with walking at slightly higher rates than "objective" environmental factors (Orstad et al. 2017; Yang et al. 2020), as objective tools do not offer much information regarding the contexts of walking paths such as neighborhood sense of community, social capital, and perceived safety, as well as general feelings experienced during a walk (Lee and Dean 2018). Table 2 provides an overview of studies on walkability under its different themes.

Urban planning research on walking dates back to when Lynch (1959) evaluated the streetscape experiences of subjects walking along selected streets. The walkers noted that some physical elements along the route were prominent to their walking experiences, such as buildings, but their strongest impressions were of the spatial qualities of individual or groups of elements, such as the breadth and width of the sidewalk. Other notable works central to supporting the importance of considering the pedestrian and understanding the use of streets were those of Lynch (1960), Jacobs (1961), Gehl (1980), Whyte (1980), Appleyard (1987), and Rapoport (1987).

Whyte (1980) pointed out people-watching as one of the main activities in public spaces. He suggested that a truly public street would have a healthy relationship between the private or the semipublic life inside its buildings and the public world outside. According to him, the way pedestrians navigate a space depends on how they understand the space, and a walkable environment 
Table 2. Review of literature on walking and walking behavior

\begin{tabular}{|c|c|c|c|}
\hline Study type & Years & Authors & Findings \\
\hline \multicolumn{4}{|c|}{ Theme: Walkability and health } \\
\hline $\begin{array}{l}\text { Objective and } \\
\text { subjective }\end{array}$ & $\begin{array}{l}1990- \\
2010 s\end{array}$ & $\begin{array}{l}\text { Mangham and Viscount (1997), Sallis and Owen (1997), } \\
\text { Bauman et al. (1999), Booth et al. (2000), Ross (2000), Ball } \\
\text { et al. (2001), Berrigan and Troiano (2002), Giles-Corti and } \\
\text { Donovan (2002, 2003), Deforche et al. (2003), Saelens et al. } \\
\text { (2003b), Leslie et al. (2005), Humpel et al. (2002), Addy et al. } \\
\text { (2004), Duncan et al. (2005) }\end{array}$ & $\begin{array}{l}\text { Geographical proximity, high rise residential areas, land use } \\
\text { mix, connectivity and accessibility, aesthetics, and safety are } \\
\text { important }\end{array}$ \\
\hline \multicolumn{4}{|c|}{ Theme: Walkability and urban planning } \\
\hline Theoretical & $\begin{array}{l}1960- \\
1990 \mathrm{~s}\end{array}$ & $\begin{array}{l}\text { Lynch (1960), Jacobs (1961), Appleyard et al. (1964), Whyte } \\
\text { (1980), Gehl (1980), Rapoport (1987) }\end{array}$ & $\begin{array}{l}\text { Walkability is supported by the urban environment and its } \\
\text { perceptual characteristics }\end{array}$ \\
\hline Theoretical & $\begin{array}{l}1980- \\
2010 s\end{array}$ & $\begin{array}{l}\text { Subtheme: The art of walking } \\
\text { Certeau (1984), Beatley and Manning (1997), Solnit (2001), } \\
\text { Pinder (2005) }\end{array}$ & $\begin{array}{l}\text { Walking as a chance for events and encounters, social } \\
\text { interactions, and excitement }\end{array}$ \\
\hline \multicolumn{4}{|c|}{ Subtheme: Pedestrian level of service } \\
\hline Theoretical & $\begin{array}{l}1990- \\
2000 \mathrm{~s}\end{array}$ & Sarkar (1993), Khisty (1994), Gallin (2001) & $\begin{array}{l}\text { Measurement of streets for pedestrians based on physical } \\
\text { features }\end{array}$ \\
\hline Theoretical & $\begin{array}{l}1960- \\
2010 s\end{array}$ & $\begin{array}{l}\text { Subtheme: Influence of built environment and per } \\
\text { Gordon (1961), Southworth (2005), Forsyth and Southworth } \\
\text { (2008), Gehl (2013) }\end{array}$ & eptions on walking \\
\hline $\begin{array}{l}\text { Objective and } \\
\text { subjective }\end{array}$ & $\begin{array}{l}1990- \\
2020 \mathrm{~s}\end{array}$ & $\begin{array}{l}\text { Handy (1993), Atash (1994), Ewing and Cervero (2001), } \\
\text { Ewing and Handy (2009), Ewing and Cervero (2010) Cervero } \\
\text { and Kockelman (1997), Hess (1997), Boarnet and Crane } \\
\text { (2001), King et al. (2003), Powell et al. (2003), Foster et al. } \\
\text { (2004), Reed et al. (2004), Abley (2005), Boarnet et al. (2005), } \\
\text { Frank et al. (2005), Forsyth (2015), Bopp et al. (2006), Seedat } \\
\text { et al. (2006), Brown et al. (2007), Cerin et al. (2007), Mehta } \\
\text { (2008), Clark et al. (2010), Yan et al. (2010), Wang et al. } \\
\text { (2012), Park (2013), Werner et al. (2018), Lee and Dean } \\
\text { (2018), Chan et al. (2021), Mezoued et al. (2021) }\end{array}$ & $\begin{array}{l}\text { Accessibility, feasibility, safety, comfort, pleasurability, } \\
\text { interesting scenery, land use mix, presence of stores, and } \\
\text { street environment are important }\end{array}$ \\
\hline
\end{tabular}

would create opportunities for meeting, sharing, and mixing with people. Rapoport (1987), on the other hand, focused more on walking in particular. He remarked that walking is supported by the urban environment and its perceptual characteristics increase the pleasures of walking. Appleyard (1987), in his book Public Streets for Public Use stated that the policies of public agencies should support the vulnerable or the soft users of the street-pedestrians, residents, children, old people, and the disabled-as healthy streets are used by different people for a variety of activities. In addition, the well-known works by Jane Jacobs have provided a robust argument for having a lively street. Her term "eyes-on-streets" has been widely used to demonstrate the importance of making a safe, livable street that will, at the same time, contribute to enhancing walkability (Jacobs 1961). Jan Gehl's works (Gehl 1980, 2013) are also among the most cited works concerning designing for pedestrians. Much like other literature that engages with design at the street and ground level, Gehl also described how urban edges and the lower floors of buildings, which he refers to as soft edges, have a strong influence on life in the city. Certeau (1984) talks about how "the act of walking is to the urban system what the speech act is to language or to the statements uttered" and that it is the chance to experience events and encounters that produces the excitement of urban life (Beatley and Manning 1997; Solnit 2001; Pinder 2005).

In planning literature, according to Cervero and Kockelman (1997) and Jacobs (1993), the most common research areas dealing with aspects of the environment that affect walking behavior comprise the three "Ds"- density, diversity, and design; acknowledging the spatial qualities first noted by Lynch (1959). Other studies in the field of urban design have been undertaken to understand the design qualities that support pedestrians. These have looked at the central factors of walkability and are mostly based on the results from transportation research.

Although "walkability" studies often measure and analyze walking based on the time spent walking by individuals, some urban design research has dealt with pedestrian movement using an empirical-quantitative approach that often deals primarily with collective patterns of behavior and their relationship to the physical environment. These attributes have been identified by focusing on different urban and neighborhood types, and on density (Handy 1993; Cervero and Kockelman 1997; Ross 2000; Boarnet and Crane 2001; Handy et al. 2002; Giles-Corti and Donovan 2003; Frank et al. 2005; Forsyth and Southworth 2008). Most studies were motivated to understand the influence of environmental attributes in encouraging physical activities such as walking. Even though studies from the medical sector provide valuable findings on effects of the built environment on physical activity, they fail to identify the important design factors behind the humanenvironment relationship with walking behavior (Chang 2012). Saelens et al. (2003b) and Chang (2012) stated that walking behavior is invariably an interplay between conscious decisions, habits, social and cultural traditions, and the immediate situation, in addition to the various properties of the built environment. It is worth recalling that a large number of these factors were already brought forth by Lynch (1960) and Jacobs (1961), who insisted on the necessity of considering them in combination (Mezoued et al. 2021).

Street network features, such as distance to places of residence and employment (Atash 1994; Hess 1997; Bauman et al. 1999; Saelens et al. 2003a; Frank et al. 2005; Curry et al. 2009), public transportation stops (King et al. 2003; Frank et al. 2005), distance to retail outlets and shopping malls (Handy 1996; Ball et al. 2001; 
Addy et al. 2004), recreation facilities (Chad et al. 2005), and parks and open spaces (King et al. 2003; Foster et al. 2004; Li et al. 2005) have all been found to be positively correlated to walking and walkability. The characteristics of sidewalks, such as presence, continuity, and quality, and their influence on walkability were also studied. Findings indicate that residents report more walking when they perceive sidewalks to be accessible or of high quality (Friedman et al. 1994; Brownson et al. 2001; Humpel et al. 2002; King et al. 2003; Powell et al. 2003; Boarnet et al. 2005; Wang et al. 2012; Werner et al. 2018).

Researchers have discussed the importance of an individual's ability to get to a destination, perceived safety, variety in land uses, and the comfort and sensory pleasures offered by the walking environment. Findings suggest that, for streets, the presence of street furniture, signage and displays, a variety and range of businesses and their uniqueness, and visual preferences, such as particular building facades, have an effect on walkability (Mehta 2008; Gjerde 2015). Fears for safety have emerged as one of the most frequent barriers to walking (Jacobs 1993; Booth et al. 2000; Foster et al. 2004; Sharpe et al. 2004; Li et al. 2005).

Personal safety fears can be perceived through social incivilities, which comprise questionable-looking individuals or street confrontations, an absence of people, physical incivilities such as unattended dogs, vacant lots, and litter, and limited visual surveillance of an area, as well as potential hiding places and blocked escape routes (Jacobs 1961; Seedat et al. 2006; Brown et al. 2007). Social factors such as community-gathering places and the presence of people and activities have been found to have a positive effect on perceived safety (Jacobs 1993; Alfonzo 2005; Brown et al. 2007; Mehta 2008). These safety concerns also extend to traffic safety, with less walking reported in areas of greater traffic or traffic noise (Carver et al. 2005; van Lenthe et al. 2005).

Comfort when walking, however, has been associated with higher walking rates (Alfonzo 2005; Zakariya 2006). People's preferences for spaces in the sun or under shade along a street change with the changing seasons and weather, and areas that people perceived as having more changes in signs and displays were more used for walking (Lynch 1960; Nasar 1997; Sarkar 2003; Mehta 2008; Manaugh and El-Geneidy 2012; Hall and Ram 2019). Jacobs (1993), Alfonzo (2005), Mehta (2008), and Gehl (2013) posited that the presence of people and activities particularly added to the sensory pleasure found on the street. Even for those who did not intend to spend time in stationary activities, walking along areas with more people and activities where people were lingering, suggesting a lively character, was an attraction. Opportunities to communicate actively and passively with other people were also important criteria in people's decisions to walk. Moreover, researchers have found that the physical environment and psychological experiences were integral parts of a pedestrian event.

Given the numerous studies that have reported a large variety of variables motivating pedestrian choices when making urban trips, relatively few studies have subsequently addressed whether changes to these immediate microfeatures of the physical environment might yield more positive walking experiences and motivate people to engage in more walking. Moreover, most studies have investigated the walking perception of city residents or a specific group or subgroup of people, for example African Americans (Bopp et al. 2006).

\section{Walkability and Tourism}

There are a number of significant differences between resident and tourist walking, and this means that resident walking behavior cannot be used as a substitute for understanding tourist patterns and behaviors (Hall et al. 2017). Contrary to residents, whose travel and walking behavior is often characterized by constraints in time, frequently taken paths, and ample knowledge about the topographical features of the city, tourists are often found to wander about with an exploratory attitude (Gorrini and Bertini 2018), moving at a lower speed, and consequently making distance and streetscape character more relevant (Vojnovic 2006). During the last few decades there has been an increase in research on walking tourism and recreational walking, such as hiking, trekking, and longdistance walking in natural and rural areas (Murray and Graham 1997; Allaire 1998; Coble et al. 2003; Chhetri et al. 2004; den Breejen 2007; Cutler et al. 2014). However, little attention has been paid to walking tourism in urban areas or, more precisely, relatively short-distance walking in the built environment and in cultural settings (Yun et al. 2018), even though walking is a fundamental, universal, and significant tourist activity (Ashworth and Dietvorst 1995; Thornton et al. 1997; Shaw et al. 2000; Davies 2018; Hall and Ram 2019). According to Hall et al. (2017), "walking around a destination to experience the place is an attraction in its own right" for tourists. Tourist walkability is relevant to understanding visitor perception and satisfaction with a place, which is an important subtheme within the domain of urban tourism research (Ashworth and Page 2011).

\section{Tourist Motivation and Experience}

Walking is classed as a tourism activity as it involves travel to destinations where walking takes place (Brown et al. 2020). Tourists mostly walk with an exploratory attitude to reach points of interest or events; this walking might be solo or organized in large groups led by a guide. Tourists also stop often, either to take pictures of interesting spots or for shopping (Gorrini and Bertini 2018). Whenever tourist groups are asked about their experiences, they speak in favor of their experiences on foot; consequently, Gregory and Page (2010) stated that a walkable city should be a magnet for tourists. However, motivations to walk when it comes to tourists are diverse, and include adventure, the discovery and interpretation of heritage, experiencing the social and cultural dimensions of places, and access to locations for wildlife and nature-based tourism (Moscardo 1996; Lumsdon and Spence 2002). Dann (1981) stated that it makes little sense to view motivation as an unconscious process and to study tourist satisfaction in isolation without considering motivation. Psychologists generally agree that "a motive is an internal factor that arouses, directs and integrates a person's behavior" (Murray 1964). Essentially, a grasp of motivation reveals why individuals or groups have behaved in a certain way or why they are about to perform an action, rather than having to speculate around how personal decisions led to an event taking place.

Following on from this, Vroom (1964) formulated an expectancy model, where motivation represents the psychological needs to pursue a stated goal. To explain such a behavior, two required conditions were noted, as elaborated by Heckhausen (1989). First, to anticipate the occurrence of the stated goal there must be an expectation and second, the stated goal must have some intrinsic value or attractiveness (valence) for the subject. Therefore, motivation can be conceptualized as a product of expectancy and valence. Or in other words, an individual's motivation to perform a certain activity is a function of the expectation that he or she will be able to perform the activity and obtain the desired outcomes, and the personal value of all outcomes associated with that activity (Hsu et al. 2010). Motivation has been further studied; Edwards and Griffin (2013) demonstrated that tourists enjoy walking around a city as this is an activity that 
Table 3. Review of literature on walkability and tourism

\begin{tabular}{|c|c|c|c|c|c|}
\hline Author(s) & Aim of study & Methodology & $\begin{array}{l}\text { Location, } \\
\text { sample size }\end{array}$ & $\begin{array}{l}\text { Type of } \\
\text { sample }\end{array}$ & Results \\
\hline \multicolumn{6}{|c|}{ Theme: Walkability and tourism (theoretical) } \\
\hline Aho (2001) & Tourist walking experience & Questionnaire; interview & $\mathrm{N} / \mathrm{A}$ & N/A & N/A \\
\hline $\begin{array}{l}\text { Cole and Scott } \\
(2004)\end{array}$ & Identify place identity and people & Theoretical study & N/A & $\mathrm{N} / \mathrm{A}$ & N/A \\
\hline $\begin{array}{l}\text { Gorrini and } \\
\text { Bertini (2018) }\end{array}$ & $\begin{array}{l}\text { Identify assessment criteria for } \\
\text { evaluation of tourist walkability } \\
\text { in cities }\end{array}$ & Theoretical study & N/A & $\mathrm{N} / \mathrm{A}$ & $\begin{array}{l}\text { Criteria: usefulness, comfort, } \\
\text { safety, attractiveness, legibility }\end{array}$ \\
\hline $\begin{array}{l}\text { Henderson } \\
(2018)\end{array}$ & $\begin{array}{l}\text { Explore the meaning of } \\
\text { walkability }\end{array}$ & Theoretical study & N/A & $\mathrm{N} / \mathrm{A}$ & N/A \\
\hline Hall et al. (2017) & $\begin{array}{l}\text { Importance of tourist walkability } \\
\text { study }\end{array}$ & Theoretical study & N/A & N/A & N/A \\
\hline $\begin{array}{l}\text { Hall and Ram } \\
\text { (2019) }\end{array}$ & $\begin{array}{l}\text { Influence of weather on tourist } \\
\text { walking }\end{array}$ & Theoretical study & N/A & N/A & N/A \\
\hline \multicolumn{6}{|c|}{ Theme: Walkability and tourism (pseudo tourist) } \\
\hline $\begin{array}{l}\text { Samarasekara } \\
\text { et al. (2011) }\end{array}$ & $\begin{array}{l}\text { Streetscape influences on the } \\
\text { walking decisions of tourists }\end{array}$ & $\begin{array}{l}\text { Questionnaire; field } \\
\text { observation; rating scale; } \\
\text { photographic }\end{array}$ & $\begin{array}{l}\text { Tokyo, Saitama } \\
\text { (Japan); 16;60; } \\
87\end{array}$ & $\begin{array}{l}\text { University } \\
\text { students }\end{array}$ & $\begin{array}{l}\text { Presence of a place to walk and } \\
\text { separated from traffic are the most } \\
\text { important and the least is safety }\end{array}$ \\
\hline $\begin{array}{l}\text { Ujang and } \\
\text { Muslim (2014) }\end{array}$ & $\begin{array}{l}\text { Effect of walkability components } \\
\text { on walking experience and tourist } \\
\text { bonding to the places they visit }\end{array}$ & $\begin{array}{l}\text { Questionnaire; interviews } \\
\text { (preliminary survey); } \\
\text { photographic }\end{array}$ & $\begin{array}{l}\text { Kuala Lumpur, } \\
\text { Malaysia; } 100\end{array}$ & $\begin{array}{l}\text { University } \\
\text { students }\end{array}$ & $\begin{array}{l}\text { Best way to explore is to walk; } \\
\text { image of places influence more } \\
\text { than the actual quality and comfor }\end{array}$ \\
\hline $\begin{array}{l}\text { Mansouri and } \\
\text { Ujang (2016) }\end{array}$ & $\begin{array}{l}\text { Spatial features and tourist } \\
\text { satisfaction with walking }\end{array}$ & Questionnaire & $\begin{array}{l}\text { Kuala Lumpur, } \\
\text { Malaysia; } 330\end{array}$ & $\begin{array}{l}\text { Previous } \\
\text { data }\end{array}$ & $\begin{array}{l}\text { Diversity of activities and spatial } \\
\text { features affect tourist expectations } \\
\text { and satisfaction }\end{array}$ \\
\hline
\end{tabular}

affords them the opportunity to become connected with a place, and to utilize the totality of their senses (sight, sound, and smell) as they pass from one space to another.

Tourist experiences are highly personal, psychological phenomena built on the subjective interpretation of occurrences, the tourist's adaptability to situations, expectations, perception, and social interactions. Together these are then interpreted and integrated into individual knowledge and memories and recollection processes at tourist destinations (Hall and Page 1999; Larsen 2007; Selstad 2007; Volo 2009; Zakaria and Ujang 2015; Cutler Quinlan et al. 2018). Knowing more about these experiences could be a tool for understanding what makes places suitable for walking. According to Solnit (2001), a mere feeling of excitement from being in an unfamiliar environment might account for a unique experience as even some mundane places could be attractive to tourist eyes and might carry special meanings (Ameel and Tani 2012). Concomitantly, the tourist experience is linked to overall satisfaction with the visit, which has a vital role in the intention to revisit the place (Cole and Scott 2004; Supitchayangkool 2012).

\section{Studies on Tourist Walkability}

As explained in the section "Walkability," a systematic literature review was conducted to find the relevant studies on walkability and tourism from different databases. Using specific keywords related to this topic, the broad search results were narrowed down to 16 published works, the findings of which are shown in Tables 3 and 4 and explained in detail next.

The tourist experience was studied by Edwards et al. (2009) and Edwards and Griffin (2013), who surveyed 1,088 local and foreign tourist respondents through a retrospective postal survey in Sydney and Melbourne and found that tourists were prepared to walk between 10 and $35 \mathrm{~km}$ a day. They identified the paths of tourists using the Global Positioning System (GPS) and the key attributes that they sought in their destinations to evaluate aspects of the tourist experience. They found that domestic and international tourists differed in their expectations, and the perceived importance of destination attributes.

In another study in Tokyo, the influence of streetscape and walkability components on the walking decisions of tourists were studied by Samarasekara et al. (2011), who discovered that activity potential and exploration made a lesser contribution to the experience than the safety and comfort variables. However, even though these variables were described as providing a positive influence on tourists, the study was conducted using "virtual tourists," i.e., university students from the authors' university.

Farkić et al. (2015) conducted a preliminary questionnairebased survey in two cities in Israel using locals as well as tourists to understand first what form of transport the participants used to explore the city. If they walked, then their walking experience, satisfaction, attachment to the places, and other related issues were surveyed. The findings of this study suggested that walking was the most preferred mode of mobility in both cities and that tourists walked to explore the city, whereas locals walked for recreation. The main findings of the study were that the design of the walking infrastructure, as well as the comfort and safety of those who walk, are important for tourists as well as locals.

With Kuala Lumpur, Malaysia, as a case study, Zakaria and Ujang (2015) assessed the comfort of 400 visiting pedestrians (local and foreign) with reference to connectivity, accessibility, and safety, and discovered that physical safety was a barrier to the comfort level of tourists. Later, Ujang and Muslim (2014) studied how connectivity, accessibility, comfort, safety, attractiveness, and pleasantness affected the psychological sense of place, such as place meaning and attachment. Their study revealed how safety, comfort, connectivity, and accessibility were important for tourists, but, at the same time, problems were raised over the continuity of walkways, quality of pavements, universal accessibility, and the vehicular traffic system. Pleasantness based on shopping areas and the vibrancy and liveliness of activities was also studied; visitors had a positive response when they could experience the multicultural nature of Kuala Lumpur. However, pleasantness for a visitor based on the weather conditions was not taken into 
Table 4. Review of literature on walkability and tourism

\begin{tabular}{|c|c|c|c|c|c|}
\hline Author(s) & Aim of study & Methodology & $\begin{array}{l}\text { Location, } \\
\text { sample size }\end{array}$ & $\begin{array}{l}\text { Type of } \\
\text { sample }\end{array}$ & Results \\
\hline \multicolumn{6}{|c|}{ Theme: Walkability and tourism (retrospective postal study) } \\
\hline $\begin{array}{l}\text { Farkić et al. } \\
(2015)\end{array}$ & Reason for walking & $\begin{array}{l}\text { Questionnaire; } \\
\text { interview }\end{array}$ & Israel; 409 & $\begin{array}{l}\text { Locals and } \\
\text { tourists }\end{array}$ & $\begin{array}{l}\text { For tourists, walking, architectural } \\
\text { design, and functional requirements have } \\
\text { a positive effect }\end{array}$ \\
\hline $\begin{array}{l}\text { Edwards } \\
\text { et al. (2009) }\end{array}$ & $\begin{array}{l}\text { Identify key attributes tourists seek in } \\
\text { destinations, and their importance }\end{array}$ & $\begin{array}{l}\text { Visitor tracking (GPS); } \\
\text { questionnaire; } \\
\text { interview }\end{array}$ & $\begin{array}{l}\text { Sydney and } \\
\text { Canberra; } 1018 \\
444\end{array}$ & $\begin{array}{l}\text { Locals and } \\
\text { foreign } \\
\text { tourists }\end{array}$ & $\begin{array}{l}\text { Domestic and international tourists differ } \\
\text { in their expectations, perceived } \\
\text { importance of destination attributes; } \\
\text { repetitive touring along same path } \\
\text { uncommon }\end{array}$ \\
\hline $\begin{array}{l}\text { Edwards and } \\
\text { Griffin } \\
\text { (2013) }\end{array}$ & $\begin{array}{l}\text { Track paths of tourists and evaluate } \\
\text { aspects of tourists' experiences }\end{array}$ & $\begin{array}{l}\text { Visitor tracking (GPS); } \\
\text { interview }\end{array}$ & $\begin{array}{l}\text { Sydney and } \\
\text { Melbourne; } 154\end{array}$ & $\begin{array}{l}\text { Locals and } \\
\text { foreign } \\
\text { tourists }\end{array}$ & $\begin{array}{l}\text { Visitor information services and } \\
\text { wayfinding important }\end{array}$ \\
\hline \multicolumn{6}{|c|}{ Theme: Walkability and tourism (real tourist) } \\
\hline $\begin{array}{l}\text { Zakaria and } \\
\text { Ujang (2015) }\end{array}$ & $\begin{array}{l}\text { Pedestrians' satisfaction of comfort } \\
\text { based on their walking experience }\end{array}$ & Questionnaire & $\begin{array}{l}\text { Kuala Lumpur; } \\
400\end{array}$ & $\begin{array}{l}\text { Locals and } \\
\text { foreign } \\
\text { tourists }\end{array}$ & $\begin{array}{l}\text { Physical safety of walkways important, } \\
\text { especially along smaller streets }\end{array}$ \\
\hline $\begin{array}{l}\text { Sarmento } \\
(2017)\end{array}$ & $\begin{array}{l}\text { Tourists' rhythms and modes of } \\
\text { walking, including their } \\
\text { performances, body languages, stops } \\
\text { and advances, and gaze interactions }\end{array}$ & $\begin{array}{l}\text { Shadowing at a } \\
\text { distance, short } \\
\text { semi-directed } \\
\text { interviews }\end{array}$ & Tunisia & Tourists & $\begin{array}{l}\text { Culture, tradition of local people sought } \\
\text { by tourist, presence of people important } \\
\text { as safety measure }\end{array}$ \\
\hline $\begin{array}{l}\text { Yun et al. } \\
(2018)\end{array}$ & $\begin{array}{l}\text { Urban walking tourists' } \\
\text { spatiotemporal distribution by season }\end{array}$ & GPS, Questionnaire & Seoul & Tourists & $\begin{array}{l}\text { Moving and staying variables of urban } \\
\text { walking tourists differ significantly by } \\
\text { season; spring the best }\end{array}$ \\
\hline $\begin{array}{l}\text { Yang et al. } \\
(2020)\end{array}$ & $\begin{array}{l}\text { Perception of tourist of the quality of } \\
\text { walking system }\end{array}$ & Questionnaire & China; 623 & Tourists & Cleanliness, level of crowding important \\
\hline
\end{tabular}

account. In a subsequent study, Mansouri and Ujang (2016) indicated that the image and social aspects of place influenced visitor walking experiences more than the quality of the walkways, safety, and degree of comfort. Also, tourists were least satisfied with the activities they could be involved in as they walked. Ram and Hall (2018) highlighted the importance of studying tourist walkability and in a following study Hall and Ram (2019) reviewed the importance of weather and the climatic conditions for the walking behavior of permanent residents and tourists. A study was conducted by Yun et al. (2018) on 233 urban tourists to understand the spatiotemporal distribution of walking tourists in different seasons (2013, 2014, and 2015) on a sunny weekend. The tourists used GPS to track their movements; spring was found to be associated with the maximum number of walks and amount of stopping outside, followed by autumn, and then summer. This study only involved the younger generation and did not align the findings of the spatiotemporal density of urban walking with the tourists' psychological characteristics.

Sarmento (2017) shadowed 32 tourist parties at a distance. The parties consisted of 326 tourists. Sarmento observed their routes, stops, where they gazed, and their interactions, and found that the culture and traditions of local people are sought by tourists, and that the presence of people was a measure of tourists' feeling of safety. Even though a short semidirected survey was conducted with a few of the observed tourists, this research was mostly an observational study. In the most recent study analyzed, Yang et al. (2020) studied the perception of 312 tourists in a traffic-free zone in China as to the quality of the walking system to understand the attribute that had the largest impact on tourist satisfaction with walking there. They considered the level of crowding, cleanliness, convenience, and comfort, presence of signage, environmental art, street lighting, and shade. They found that the level of crowding and cleanliness were important. Nevertheless, this study was conducted on tourists rather than both tourists and locals, and a comparison of both groups would be necessary for a full understanding of which urban attributes encourage walking for all.
Even though these studies in the area of tourist walkability look helpful, they have some shortcomings. Samarasekara et al. (2011) and Ujang and Muslim (2014) conducted their study on virtual tourists. Edwards et al. (2009) and Edwards and Griffin (2013) conducted a postal survey that might result in loss of information from fading memories with time. Yun et al. (2018), as already mentioned, conducted their study on the younger technology-wise generation and did not consider the personal attributes that could affect walking behavior. The study by Sarmento (2017) was conducted during the day and did not consider nighttime walking, which, according to the author, could be a different experience. Finally, the study by Yang et al. (2020) was conducted in a traffic-free zone on tourists, without considering local residents.

The findings from the studies on tourist walkability and their limitations point toward a need to study tourist walkability by considering both locals and tourists, in order to understand whether there are differences in their perception of walkability and what environmental and psychological attributes affect them.

\section{Summary and Conclusion}

This paper gives a review of the literature on walkability and walking behavior with a focus on the tourist experience, a study area that has, to date, been overlooked. People live in cities and experience them firsthand, and it is clear that each place can be viewed from a variety of perspectives. There will be differences between what tourists and locals see in a place, in how they feel, and between the viewpoints of old and new residents as "People live in different worlds even though they share the same locality: there is no single community or quarter. What is pleasantly 'old' for one person is decayed and broken for another" (Wright 1985). Although there are indications and preliminary results that manifest some of these relationships, the study deserves deeper investigation in order to generate primary data about tourist walking attitudes and behavior. 


\section{Future Research}

This review of research in the field of tourist walkability provides a good starting point for future research. Further studies could investigate the similarities and differences in the perception of urban walking routes of both residents and tourists to understand which attributes influence the walking behavior, and whether both groups appreciate the same attributes. This could be achieved by conducting a survey in cities using a mixed-method approach. The intention is to follow this review with such a study of walking tourists and residents in two cities in New Zealand and to feed the information gained back to the local planners and urban designers, in the hope of encouraging more walking and less dependency on motorized travel in cities.

\section{Data Availability Statement}

Some or all data, models, or code that support the findings of this study are available from the corresponding author on reasonable request.

\section{References}

Abley, S. 2005. "Walkability scoping paper." Christchurch, New Zealand: Abley Transportation Consultants.

Addy, C. L., D. K. Wilson, K. A. Kirtland, B. E. Ainsworth, P. Sharpe, and D. Kimsey. 2004. "Associations of perceived social and physical environmental supports with physical activity and walking behavior." Am. J. Public Health 94 (3): 440-443. https://doi.org/10.2105/AJPH 94.3.440.

Aho, S. K. 2001. "Towards a general theory of touristic experiences: Modelling experience process in tourism." Tourism Rev. $56(3+4)$ : 33-37. https://doi.org/10.1108/eb058368.

Alfonzo, M. A. 2005. "To walk or not to walk? The hierarchy of walking needs." Environ. Behav. 37 (6): 808-836. https://doi.org/10.1177 /0013916504274016.

Allaire, G. 1998. "Medieval Italian pilgrims to Santiago de Compostela: New literary evidence." J. Medieval Hist. 24 (2): 177-189. https://doi .org/10.1016/S0304-4181(98)00004-9.

Ameel, L., and S. Tani. 2012. "Everyday aesthetics in action: Parkour eyes and the beauty of concrete walls." Emotion Space Soc. 5 (3): 164-173. https://doi.org/10.1016/j.emospa.2011.09.003.

Appleyard, D. 1987. Public streets for public use. New York: Van Nostrand Reinhold.

Appleyard, D., K. Lynch, and J. R. Myer. 1964. The view from the road. Cambridge, MA: MIT Press.

Ashworth, G., and S. J. Page. 2011. "Urban tourism research: Recent progress and current paradoxes.” Tourism Manage. 32 (1): 1-15. https://doi .org/10.1016/j.tourman.2010.02.002.

Ashworth, G. J., and A. G. J. Dietvorst. 1995. "Tourism and spatial transformations." In Tourist behaviour and the importance of time-space analysis, 163-181. Wallingford, UK: Cab International.

Atash, F. 1994. "Redesigning suburbia for walking and transit: Emerging concepts.” J. Urban Plann. Dev. 120 (1): 48-57. https://doi.org/10 .1061/(ASCE)0733-9488(1994)120:1(48).

Ball, K., A. Bauman, E. Leslie, and N. Owen. 2001. "Perceived environmental aesthetics and convenience and company are associated with walking for exercise among Australian adults." Preventive Med. 33 (5): 434-440. https://doi.org/10.1006/pmed.2001.0912.

Bauman, A., B. Smith, L. Stoker, B. Bellew, and M. Booth. 1999. "Geographical influences upon physical activity participation: Evidence of a 'coastal effect'." Aust. N.Z. J. Public Health 23 (3): 322-324. https://doi.org/10.1111/j.1467-842X.1999.tb01265.x.

Beatley, T., and K. Manning. 1997. The ecology of place: Planning for environment, economy, and community. Washington, DC: Island Press.
Berrigan, D., and R. P. Troiano. 2002. "The association between urban form and physical activity in US adults." Am. J. Preventive Med. 23 (2): 74-79. https://doi.org/10.1016/S0749-3797(02)00476-2.

Boarnet, M., and R. Crane. 2001. "The influence of land use on travel behavior: Empirical strategies.” Transp. Res. A 35: 823-845.

Boarnet, M. G., C. L. Anderson, K. Day, T. McMillan, and M. Alfonzo. 2005. "Evaluation of the California Safe Routes to School legislation: Urban form changes and children's active transportation to school." Am. J. Preventive Med. 28 (2): 134-140. https://doi.org/10.1016/j .amepre.2004.10.026.

Boland, A., G. Cherry, and R. Dickson. 2017. Doing a systematic review: A student's guide. 2nd ed. Philadelphia: Sage.

Booth, M. L., N. Owen, A. Bauman, O. Clavisi, and E. Leslie. 2000. "Social-cognitive and perceived environment influences associated with physical activity in older Australians." Preventive Med. 31 (1): 15-22. https://doi.org/10.1006/pmed.2000.0661.

Bopp, M., S. Wilcox, M. Laken, K. Butler, R. E. Carter, L. McClorin, and A. Yancey. 2006. "Factors associated with physical activity among African-American men and women." Am. J. Preventive Med. 30 (4): 340-346. https://doi.org/10.1016/j.amepre.2005.11.007.

Brown, B. B., C. M. Werner, J. W. Amburgey, and C. Szalay. 2007. "Walkable route perceptions and physical features: Converging evidence for en route walking experiences." Environ. Behav. 39 (1): 34-61. https://doi.org/10.1177/0013916506295569.

Brown, L., D. de Coteau, and N. Lavrushkina. 2020. "Taking a walk: The female tourist experience.” Tourist Stud. 20 (3): 354-370. https://doi .org/10.1177/1468797620930036.

Brownson, R. C., E. A. Baker, R. A. Housemann, L. K. Brennan, and S. J. Bacak. 2001. "Environmental and policy determinants of physical activity in the United States." Am. J. Public Health 91 (12): 1995 2003. https://doi.org/10.2105/AJPH.91.12.1995.

Carver, A., J. Salmon, K. Campbell, L. Baur, S. Garnett, and D. Crawford. 2005. "How do perceptions of local neighborhood relate to adolescents' walking and cycling?" Am. J. Health Promot. 20 (2): 139-147. https:// doi.org/10.4278/0890-1171-20.2.139.

Cerin, E., E. Leslie, L. du Toit, N. Owen, and L. D. Frank. 2007. "Destinations that matter: Associations with walking for transport." Health Place 13 (3): 713-724. https://doi.org/10.1016/j.healthplace 2006.11.002.

Certeau, M. D. 1984. The practice of everyday life. Translated by S. Rendall. Berkeley, CA: University of California Press.

Cervero, R., and K. Kockelman. 1997. "Travel demand and the 3ds: Density, diversity, and design." Transp. Res. Part D Transp. Environ. 2 (3): 199-219. https://doi.org/10.1016/S1361-9209(97)00009-6.

Chad, K. E., B. A. Reeder, E. L. Harrison, N. L. Ashworth, S. M. Sheppard, S. L. Schultz, B. G. Bruner, K. L. Fisher, and J. A. Lawson. 2005. "Profile of physical activity levels in community-dwelling older adults." Med. Sci. Sports Exercise 37 (10): 1774-1784. https://doi.org/10.1249 /01.mss.0000181303.51937.9c.

Chan, E. T., T. E. Li, T. Schwanen, and D. Banister. 2021. "People and their walking environments: An exploratory study of meanings, place and times." Int. J. Sustainable Transp. 15 (9): 718-729. https://doi .org/10.1080/15568318.2020.1793437.

Chang, T. C. 2012. "Walking as an urban design problem; Understanding the activity of walking in the urban environment." $\mathrm{Ph} . \mathrm{D}$. thesis, School of Architecture and the Built Environment, KTH Royal Institute of Technology.

Cherrill, G., and M. Donn. 2020. "Methods to assess the risk of condensation from thermal bridges in timber-framed houses: A systematic literature review." In Proc., 54th Int. Conf. of the Architectural Science Association, 1-10. Architectural Science Association. Accessed May 21, 2021. https://anzasca.net/.

Chhetri, P., C. Arrowsmith, and M. Jackson. 2004. "Determining hiking experiences in nature-based tourist destinations." Tourism Manage. 25 (1): 31-43. https://doi.org/10.1016/S0261-5177(03) 00057-8.

Clark, M. I., T. R. Berry, J. C. Spence, C. Nykiforuk, M. Carlson, and C. Blanchard. 2010. "Key stakeholder perspectives on the development of walkable neighbourhoods." Health Place 16 (1): 43-50. https://doi.org /10.1016/j.healthplace.2009.08.001. 
Coble, T. G., S. W. Selin, and B. B. Erickson. 2003. "Hiking alone: Understanding fear, negotiation strategies and leisure experience." J. Leisure Res. 35 (1): 1-22. https://doi.org/10.18666/jlr-2003-v35-i1-608.

Cole, S. T., and D. Scott. 2004. "Examining the mediating role of experience quality in a model of tourist experiences." J. Travel Tourism Marketing 16 (1): 79-90. https://doi.org/10.1300/J073v16n01_08.

Curry, L. A., I. M. Nembhard, and E. H. Bradley. 2009. "Qualitative and mixed methods provide unique contributions to outcomes research." Circulation 119 (10): 1442-1452. https://doi.org/10.1161/CIRCULA TIONAHA.107.742775.

Cutler, S. Q., B. Carmichael, and S. Doherty. 2014. "The Inca Trail experience: Does the journey matter?" Ann. Tourism Res. 45: 152-166. https://doi.org/10.1016/j.annals.2013.12.016.

Cutler Quinlan, S., S. Doherty, B. Carmichael. 2018. "The experience sampling method: Examining its use and potential in tourist experience research." Curr. Issues Tourism 21 (9): 1052-1074. https://doi.org/10 .1080/13683500.2015.1131670.

Dann, G. M. 1981. "Tourist motivation an appraisal." Ann. Tourism Res. 8 (2): 187-219. https://doi.org/10.1016/0160-7383(81)90082-7.

Davies, N. 2018. "Who walks, where and why? Practitioners' observations and perspectives on recreational walkers at UK tourist destinations." Ann. Leisure Res. 21 (5): 553-574. https://doi.org/10.1080/11745398 .2016.1250648.

Deforche, B., J. Lefevre, I. De Bourdeaudhuij, A. P. Hills, W. Duquet, and J. Bouckaert. 2003. "Physical fitness and physical activity in obese and nonobese flemish youth.” Obesity Res. 11 (3): 434-441. https://doi.org /10.1038/oby.2003.59.

den Breejen, L. 2007. "The experiences of long distance walking: A case study of the West Highland Way in Scotland." Tourism Manage. 28 (6): 1417-1427. https://doi.org/10.1016/j.tourman.2006.12.004.

Duncan, M. J., J. C. Spence, and W. K. Mummery. 2005. "Perceived environment and physical activity: A meta-analysis of selected environmental characteristics." Int. J. Behav. Nutr. Phys. Act. 2 (1): 1-9. https://doi .org/10.1186/1479-5868-2-11.

Edwards, D., and T. Griffin. 2013. "Understanding tourists' spatial behaviour: GPS tracking as an aid to sustainable destination management." J. Sustainable Tourism 21 (4): 580-595. https://doi.org/10.1080 /09669582.2013.776063.

Edwards, D., T. Griffin, B. Hayllar, T. Dickson, and S. Schweinsberg. 2009. Understanding tourist 'experiences' and 'behaviour' in cities. Rep. Gold Coast, Queensland: Sustainable Tourism Co-operative Research Centre.

Ewing, R., and R. Cervero. 2001. "The influence of land use on travel behavior: Empirical strategies." Transp. Res. Policy Pract. 35: 823-845. https://doi.org/10.1016/S0965-8564(00)00019-7.

Ewing, R., and R. Cervero. 2010. "Travel and the built environment: A meta-analysis.” J. Am. Plann. Assoc. 76 (3): 265-294. https://doi.org /10.1080/01944361003766766.

Ewing, R., and S. Handy. 2009. "Measuring the unmeasurable: Urban design qualities related to walkability." J. Urban Des. 14 (1): 65-84. https://doi.org/10.1080/13574800802451155.

Farkić, J., D. Perić, M. Lesjak, and M. Petelin. 2015. "Urban walking: Perspectives of locals and tourists." Geog. Pannonica 19 (4): 212 222. https://doi.org/10.5937/GeoPan1504212F.

Forsyth, A. 2015. "What is a walkable place? The walkability debate in urban design." Urban Des. Int. 20 (4): 274-292. https://doi.org/10 .1057/udi.2015.22.

Forsyth, A., and M. Southworth. 2008. "Cities afoot-pedestrians, walkability and urban design." J. Urban Des. 13 (1): 1-3. https://doi.org/10 .1080/13574800701816896.

Foster, C., M. Hillsdon, and M. Thorogood. 2004. "Environmental perceptions and walking in English adults.” J. Epidemiol. Community Health 58 (11): 924-928. https://doi.org/10.1136/jech.2003.014068.

Frank, L. D., T. L. Schmid, J. F. Sallis, J. Chapman, and B. E. Saelens. 2005. "Linking objectively measured physical activity with objectively measured urban form: Findings from SMARTRAQ." Am. J. Preventive Med. 28 (2): 117-125. https://doi.org/10.1016/j.amepre.2004.11.001.

Friedman, B., S. P. Gordon, and J. B. Peers. 1994. "Effect of neotraditional neighborhood design on travel characteristics." Transp. Res. Rec. 1466: 63-70.
Gallin, N. 2001. "Quantifying pedestrian friendliness-guidelines for assessing pedestrian level of service." Road Transp. Res. 10 (1): 47.

Gehl, J. 1980. Vol. 23 of Life between buildings. New York: Van Nostrand Reinhold.

Gehl, J. 2013. Cities for people. Washington, DC: Island press.

Gehl, J. 2017. "How to build a good city." Interview. October 4, 2017. https://www.youtube.com/watch?v=9_x5Hor2MP8.

Gilderbloom, J. I., W. W. Riggs, and W. L. Meares. 2015. "Does walkability matter? An examination of walkability's impact on housing values, foreclosures and crime." Cities 42: 13-24. https://doi.org/10.1016/j .cities.2014.08.001

Giles-Corti, B., and R. J. Donovan. 2002. "The relative influence of individual, social and physical environment determinants of physical activity." Social Sci. Med. 54 (12): 1793-1812. https://doi.org/10.1016 /S0277-9536(01)00150-2.

Giles-Corti, B., and R. J. Donovan. 2003. "Relative influences of individual, social environmental, and physical environmental correlates of walking." Am. J. Public Health 93 (9): 1583-1589. https://doi.org/10 .2105/AJPH.93.9.1583.

Gjerde, M. 2015. "Street perceptions: A study of visual preferences for New Zealand streetscapes." Ph.D. thesis, School of Architecture, Victoria Univ. of Wellington.

Gordon, C. 1961. The concise townscape. London: Reed Educational and Professional Publishing.

Gorrini, A., and V. Bertini. 2018. "Walkability assessment and tourism cities: The case of Venice." Int. J. Tourism Cities 4 (3): 355-368. https:// doi.org/10.1108/IJTC-11-2017-0072.

Gregory, A., and S. J. Page. 2010. "Urban tourism research: Recent progress and current paradoxes." Tourism Manage 32 (1): 1-15. https:/ /doi.org/10.1016/j.tourman.2010.02.002.

Hall, C. M., D.-T. Le-Klähn, and Y. Ram. 2017. Tourism, public transport and sustainable mobility. Bristol, UK: Channel View Publications.

Hall, C. M., and S. J. Page. 1999. The geography of tourism and recreation: Environment, place and space. Abingdon, UK: Routledge.

Hall, C. M., and Y. Ram. 2019. "Weather and climate in the assessment of tourism-related walkability." Int. J. Biometeorol. 65: 729-739. https:// doi.org/10.1007/s00484-019-01801-2.

Handy, S. 1993. "Regional versus local accessibility: Implications for nonwork travel." Transp. Res. Rec. 1400: 58-66.

Handy, S. L. 1996. "Understanding the link between urban form and nonwork travel behavior." J. Plann. Educ. Res. 15 (3): 183-198. https://doi .org/10.1177/0739456X9601500303.

Handy, S. L., M. G. Boarnet, R. Ewing, and R. E. Killingsworth. 2002. "How the built environment affects physical activity: Views from urban planning." Am. J. Preventive Med. 23 (2): 64-73. https://doi .org/10.1016/S0749-3797(02)00475-0.

Heckhausen, H. 1989. Motivation and action. Berlin: Springer.

Henderson, J. 2018. "Making cities more walkable for tourists: A view from Singapore's streets." Int. J. Tourism Cities 4 (3): 285-297. https://doi.org/10.1108/IJTC-11-2017-0059.

Hess, P. M. 1997. "Measures of connectivity [streets: Old paradigm, new investment]." Places 11 (2): 58-65.

Hsu, C. H., L. A. Cai, and M. Li. 2010. "Expectation, motivation, and attitude: A tourist behavioral model." J. Travel Res. 49 (3): 282-296. https://doi.org/10.1177/0047287509349266.

Humpel, N., N. Owen, and E. Leslie. 2002. "Environmental factors associated with adults' participation in physical activity: A review." Am. J. Preventive Med. 22 (3): 188-199. https://doi.org/10.1016/S0749-3797(01)00426-3.

Jacobs, J. 1961. The death and life of American Cities. New York: Random House.

Jacobs, J. 1993. Great streets. Cambridge: MIT Press.

Khisty, C. J. 1994. "Evaluation of pedestrian facilities: Beyond the level-of-service concept." Transp. Res. Rec. 1438: 45-50.

King, W. C., J. S. Brach, S. Belle, R. Killingsworth, M. Fenton, and A. M. Kriska. 2003. "The relationship between convenience of destinations and walking levels in older women." Am. J. Health Promot. 18 (1): 74-82. https://doi.org/10.4278/0890-1171-18.1.74.

Larsen, S. 2007. "Aspects of a psychology of the tourist experience." Scand. J. Hospitality Tourism 7 (1): 7-18. https://doi.org/10.1080 /15022250701226014. 
Lee, E., and J. Dean. 2018. "Perceptions of walkability and determinants of walking behaviour among urban seniors in Toronto, Canada." J. Transp. Health 9: 309-320. https://doi.org/10.1016/j.jth.2018.03.004.

Leslie, E., B. Saelens, L. Frank, N. Owen, A. Bauman, N. Coffee, and G. Hugo. 2005. "Residents' perceptions of walkability attributes in objectively different neighbourhoods: A pilot study." Health Place 11 (3): 227-236. https://doi.org/10.1016/j.healthplace.2004.05.005.

Leyden, K. M. 2003. "Social capital and the built environment: The importance of walkable neighborhoods." Am. J. Public Health 93 (9): 15461551. https://doi.org/10.2105/AJPH.93.9.1546.

Li, F., K. J. Fisher, and R. C. Brownson. 2005. "A multilevel analysis of change in neighborhood walking activity in older adults." J. Aging Phys. Act. 13 (2): 145-159. https://doi.org/10.1123/japa.13.2.145.

Lumsdon, L., and J. Spence. 2002. "Rationale and design of urban recreational walking trails in several cities in the UK." In Proc., Walk 21-3rd Conf.: Steps Towards Livable Cities, 56-68. Accessed June 11, 2021. https://walk21.com/work/conference/.

Lynch, K. 1959. "A walk around the block.” Landscape 8: 24-34.

Lynch, K. 1960. The image of the city, 1st ed. Massachusetts, MA: MIT Press.

Manaugh, K., and A. M. El-Geneidy. 2012. "What makes travel 'local' defining and understanding local travel behavior." J. Transp. Land Use 5 (3): $15-27$.

Mangham, C., and P. W. Viscount. 1997. "Along the boardwalk: Effects of a boardwalk on walking behaviour within a Nova Scotia community." Can. J. Public Health 88 (5): 325. https://doi.org/10.1007 /BF03403899.

Mansouri, M., and N. Ujang. 2016. "Tourist'expectation and satisfaction towards pedestrian networks in the historical district of Kuala Lumpur, Malaysia.” Asian Geogr. 33 (1): 35-55. https://doi.org/10 1080/10225706.2016.1185639.

Mehta, V. 2008. "Walkable streets: Pedestrian behavior, perceptions and attitudes." J. Urbanism 1 (3): 217-245.

Mezoued, A. M., Q. Letesson, and V. Kaufmann. 2021. "Making the slow metropolis by designing walkability: A methodology for the evaluation of public space design and prioritizing pedestrian mobility." Urban Res. Pract. 1-20. https://doi.org/10.1080/17535069.2021 1875038 .

Millington, C., C. W. Thompson, D. Rowe, P. Aspinall, C. Fitzsimons, N. Nelson, and N. Mutrie 2009. "Development of the Scottish walkability assessment tool (SWAT)." Health Place 15 (2): 474-481. https://doi org/10.1016/j.healthplace.2008.09.007.

Moscardo, G. 1996. "Mindful visitors: Heritage and tourism." Ann. Tourism Res. 23 (2): 376-397. https://doi.org/10.1016/0160-7383(95)00068-2.

Murray, D. 1964. "Book review: Motivation and emotion." Q. J. Exp. Psychol. 16 (2): 191-192.

Murray, M., and B. Graham. 1997. "Exploring the dialectics of route-based tourism: The Camino de Santiago." Tourism Manage. 18 (8): 513-524. https://doi.org/10.1016/S0261-5177(97)00075-7.

Nasar, J. L. 1997. "New developments in aesthetics for urban design." In Toward the integration of theory, methods, research, and utilization, 149-193. Berlin: Springer.

Orstad, S. L., M. H. McDonough, S. Stapleton, C. Altincekic, and P. J. Troped. 2017. "A systematic review of agreement between perceived and objective neighborhood environment measures and associations with physical activity outcomes." Environ. Behav. 49 (8): 904-932. https://doi.org/10.1177/0013916516670982.

Park, D. 2013. "International study on factor structure to create a city center vibrant with pedestrians-a field survey of Kyoto, Seoul, Beijing and Florence." Ph.D. thesis, Graduate School of Engineering, Kyoto Univ.

Phillips, E. M., J. C. Schneider, and G. R. Mercer. 2004. "Motivating elders to initiate and maintain exercise." Arch. Phys. Med. Rehabil. 85: 52-57. https://doi.org/10.1016/j.apmr.2004.03.012.

Phillips, J., N. Walford, A. Hockey, N. Foreman, and M. Lewis. 2013. "Older people and outdoor environments: Pedestrian anxieties and barriers in the use of familiar and unfamiliar spaces." Geoforum 47: 113124. https://doi.org/10.1016/j.geoforum.2013.04.002.

Pinder, D. 2005. "Arts of urban exploration." Cultural Geographies 12 (4): 383-411. https://doi.org/10.1191/1474474005eu347oa.
Powell, K. E., L. M. Martin, and P. P. Chowdhury. 2003. "Places to walk: Convenience and regular physical activity." Am. J. Public Health 93 (9): 1519-1521. https://doi.org/10.2105/AJPH.93.9.1519.

Ram, Y., and C. M. Hall. 2018. "Walking tourism in cities: Introducing the special issue.” Int. J. Tourism Cities 4 (3): 281-284. https://doi.org/10 1108/IJTC-09-2018-098.

Rapoport, A. 1987. "Pedestrian street use: Culture and perception." In Public streets for public use, edited by A. Moudon, 80-94. New York: Van Nostrand Reinhold.

Reed, J. A., B. E. Ainsworth, D. K. Wilson, G. Mixon, and A. Cook. 2004. "Awareness and use of community walking trails." Preventive Med. 39 (5): 903-908. https://doi.org/10.1016/j.ypmed .2004.03.013

Ross, C. E. 2000. "Walking, exercising, and smoking: Does neighborhood matter?" Social Sci. Med. 51 (2): 265-274. https://doi.org/10.1016 /S0277-9536(99)00451-7.

Saelens, B. E., J. F. Sallis, J. B. Black, and D. Chen. 2003a "Neighborhood-based differences in physical activity: An environment scale evaluation." Am. J. Public Health 93 (9): 1552-1558. https://doi .org/10.2105/AJPH.93.9.1552.

Saelens, B. E., J. F. Sallis, and L. D. Frank. 2003b. "Environmental correlates of walking and cycling: Findings from the transportation, urban design, and planning literatures." Ann. Behav. Med. 25 (2): 80-91. https://doi.org/10.1207/S15324796ABM2502_03.

Sallis, J. F., and N. Owen. 1997. "Ecological models." In Health behavior and health education: Theory, research and practice. San Francisco: Jossey-Bass.

Samarasekara, G. N., K. Fukahori, and Y. Kubota. 2011. "Environmental correlates that provide walkability cues for tourists: An analysis based on walking decision narrations." Environ. Behav. 43 (4): 501-524. https://doi.org/10.1177/0013916510379350.

Sarkar, S. 1993. "Determination of service levels for pedestrians, with European examples." Transp. Res. Rec. 1405: 35-42.

Sarkar, S. 2003. "Qualitative evaluation of comfort needs in urban walkways in major activity centers." Transp. Q. 57 (4): 39-59.

Sarmento, J. 2017. "Tourists' walking rhythms: 'doing' the Tunis Medina, Tunisia.” Social Cultural Geogr. 18 (3): 295-314. https://doi.org/10 .1080/14649365.2016.1174283.

Seedat, M., S. MacKenzie, and D. Mohan. 2006. "The phenomenology of being a female pedestrian in an African and an Asian city: A qualitative investigation." Transp. Res. Part F Traffic Psychol. Behav. 9 (2): 139153. https://doi.org/10.1016/j.trf.2005.09.005.

Selstad, L. 2007. "The social anthropology of the tourist experience. Exploring the 'middle role'." Scand. J. Hospitality Tourism 7 (1): 19-33. https://doi.org/10.1080/15022250701256771.

Sharpe, P. A., M. L. Granner, B. Hutto, and B. E. Ainsworth. 2004 "Association of environmental factors to meeting physical activity recommendations in two South Carolina counties." Am. J. Health Promot. 18 (3): 251-257. https://doi.org/10.4278/0890-1171-18.3.251.

Shaw, G., S. Agarwal, and P. Bull. 2000. "Tourism consumption and tourist behaviour: A British perspective." Tourism Geographies 2 (3): 264-289. https://doi.org/10.1080/14616680050082526.

Solnit, R. 2001. Wanderlust: A history of walking. London: Penguin.

Southworth, M. 2005. "Designing the walkable city." J. Urban Plann. Dev. 131 (4): 246-257. https://doi.org/10.1061/(ASCE)0733-9488(2005) 131:4(246).

Supitchayangkool, S. 2012. "The differences between satisfied/dissatisfied tourists towards service quality and revisiting Pattaya, Thailand." Int. J. Bus. Manage. 7 (6): 30-39. https://doi.org/10.5539/ijbm.v7n6p30.

Thompson, K. J. 2003. "Urban transport networks and overseas visitors: Analysis of the factors affecting usage and the implications for destination management." Ph.D. thesis, School of the Built Environment, Univ. of Salford.

Thornton, P., A. Williams, and G. Shaw. 1997. "Revisiting time-space diaries: An exploratory case study of tourist behaviour in Cornwall, England." Environ. Plann. A 29 (10): 1847-1867. https://doi.org/10 .1068/a291847.

Ujang, N., and Z. Muslim. 2014. "Walkability and attachment to tourism places in the city of Kuala Lumpur, Malaysia." Athens J. Tourism 2 (1): $53-65$. 
van Lenthe, F. J., J. Brug, and J. P. Mackenbach 2005. "Neighbourhood inequalities in physical inactivity: The role of neighbourhood attractiveness, proximity to local facilities and safety in the Netherlands." Social Sci. Med. 60 (4): 763-775. https://doi.org/10.1016/j.socscimed.2004.06 .013 .

Vojnovic, I. 2006. "Building communities to promote physical activity: A multi-scale geographical analysis." Geogr. Ann. Ser. B Hum. Geogr. 88 (1): 67-90. https://doi.org/10.1111/j.0435-3684.2006 .00206.x.

Volo, S. 2009. "Conceptualizing experience: A tourist based approach." J. Hospitality Marketing Manage. 18 (2-3): 111-126. https://doi.org /10.1080/19368620802590134.

Vroom, V. H. 1964. Work and motivation. New York: Wiley.

Wang, W., P. Li, W. Wang, and M. Namgung. 2012. "Exploring determinants of pedestrians' satisfaction with sidewalk environments: Case study in Korea." J. Urban Plann. Dev. 138 (2): 166-172. https://doi .org/10.1061/(ASCE)UP.1943-5444.0000105.

Werner, C. M., B. B. Brown, T. Stump, C. P. Tribby, W. Jensen, H. J. Miller, A. Strebel, and A. Messina. 2018. "Street use and design: Daily rhythms on four streets that differ in rated walkability." J. Urban Des. 23 (4): 603-619. https://doi.org/10.1080/13574809 .2018.1448706.

Whyte, W. H. 1980. The social life of small urban spaces. Washington, DC: Conservation Foundation.
World Tourism Organisation. 2008. "United Nations standards for measuring tourism: Glossary of tourism terms.” Accessed July 2, 2021. https:// www.unwto.org/glossary-tourism-terms.

Wright, P. 1985. On living in an old country: The national past in contemporary Britain. Oxford, UK: Oxford University Press.

Yan, A. F., C. C. Voorhees, K. Clifton, and C. Burnier. 2010. "“Do you see what I see?' -Correlates of multidimensional measures of neighborhood types and perceived physical activity-related neighborhood barriers and facilitators for urban youth." Preventive Med. 50: S18-S23. https://doi .org/10.1016/j.ypmed.2009.08.015.

Yang, L., X. Wang, G. Sun, and Y. Li. 2020. "Modeling the perception of walking environmental quality in a traffic-free tourist destination." J. Travel Tourism Marketing 37 (5): 608-623. https://doi.org/10.1080 /10548408.2019.1598534.

Yun, H. J., D. J. Kang, and M. J. Lee. 2018. "Spatiotemporal distribution of urban walking tourists by season using GPS-based smartphone application." Asia Pac. J. Tourism Res. 23 (11): 1047-1061. https://doi.org/10 $.1080 / 10941665.2018 .1513949$.

Zakaria, J., and N. Ujang. 2015. "Comfort of walking in the city center of Kuala Lumpur." Procedia-Social Behav. Sci. 170: 642-652. https://doi .org/10.1016/j.sbspro.2015.01.066.

Zakariya, K. 2006. "Refining tourist's place experience through placemaking: A case study on Middle East tourists in Kuala Lumpur city centre." Ph.D. thesis, Faculty of Built Environment, Univ. Technology Malaysia. 